\title{
琹性リンパ腫の染色体分析 \\ Chromosomal Analysis of Malignant Lymphomas
}

\author{
*国立がんセンター研究所病理部 \\ **国立病院医療センター臨床研究部遗伝疫学室 \\ 黒木 将 仁*, 渡 辺 昌* \\ 長谷川 知 子**
}

（昭和56年 1 月 21 日受付）

染色体分析は染色体異常を伴な5よ5な先天性疾患 に於いては診断上必須のものであるが，その他の疾 患, とくに腫瑒に於いては核型異常が頻発するために その分析は困難もしくは不可能なことが多い。造血系 腫癔に於いては慢性骨膸性白血病に於ける $\mathrm{Ph}^{1}$ 染色 体の存在が共通していることは周知の事実であるが, それが原因か結果かといらことになると末だ不明確な ままである。しかし $\mathrm{Ph}^{1}$ 染色体の探求から急性骨髄 性白血病・急性リンパ性白血病の一部にも $\mathrm{Ph}^{1}$ 染色 体の存在する例が見つかり，そのような例では予後が 悪いために診断上の価值が大きい(2)，(3)。悪性リン パ腫に於いては Burkitt リンパ腫の $14 \mathrm{q}+$ 染色体の 存在が報告されているが(9)，(10)，(22)，これら染色 体異常が腫湟化の原因なのか，結果なのかということ については全く不明である。

いずれにせよ未だ染色体分析の研究は個々の症例の 分析を積み上げていく段階にある。またその結果を腫 櫁細胞の膜形質や機能状態, 細胞組織形態上の特徽な ぞと比較検討させていくことが必要である。

我々も数年来, 覀性リンパ腫の染色体分析を武みて きているが，その結果を報告し読者の御批判をあおぎ たい。

\section{材料と方法}

症例 : 症例は1978年から1980年のほ潘 3 年間に国立 がんセンター病院に於いて生検・手術をらけた悪性り ンパ腫症例のうち, 組織診於及び marker の検索が でき, かつ染色体分析の可能であった43例と, 悪性り ンパ腫を疑われた反応性肥大 4 例の計 47 例である。
悪性リンパ腫の組織彭断は LSG 分類(17)にもとつう き, 沪胞性リンパ腫 9 例, びまん性りンパ腫中細胞型 2 例, 大細胞型19例, 多形細胞型 3 例, リンバ芽球型 2 例, IBL上5 T リンパ腫 (7) 5 例, ホジキン病 3 例で ある(表 1 )。

表 1 症例と診断

\begin{tabular}{|c|c|c|}
\hline 組 織 誩 断 & 表現型 & 症例数 \\
\hline 沪胞性リンパ腫 (nodular) & B & 9 \\
\hline びまん性大細胞型 & B & 18 \\
\hline (diffuse large lymphoid) & null & 1 \\
\hline 多形細胞型 (pleomorphic) & $\mathrm{T}$ & 3 \\
\hline $\begin{array}{l}\text { リンパ芽球 型 } \\
\text { (lymphoblastic) }\end{array}$ & $\mathrm{T} /$ non'T-non $\mathrm{B}$ & 2 \\
\hline びまん性中細胞型 (P.D.L) & $\mathrm{T} / \mathrm{B}$ & 2 \\
\hline IBLようTリンパ腫 & $\mathrm{T}$ & 5 \\
\hline ホジキン病 & & 3 \\
\hline 反応性肥大 & & 4 \\
\hline
\end{tabular}

検体の処理：生検・手術材料を牛胎児血清 $20 \%$ 加 RPMI1640 培地の中で細切し, colcemid を0.01〜 $0.1 \mu \mathrm{g} / \mathrm{m \ell}$ になるよ5に加えて $1 \sim 24$ 時間 $\mathrm{CO}_{2}$ incubator 中で培養した。培養時間は新鮮材料の择印標本 を鏡検し，分裂像の頻度によって適当に調整した。培 養後細胞を回収し遠沈洗浄後 $0.075 \mathrm{M} \mathrm{KCl}$ 溶液を加 えて $37^{\circ} \mathrm{C} 15 \sim 20$ 分低張処理し, 800 r.p.m. 10分遠沈 後上澄みを半量唅てメタノール:酰酸 $(3: 1)$ 固定液 を静かに 1 滴ずつ等量加え半固定の状態で10分間室温 で静置した。以後は更に遠沈，固定液交換を $3 \sim 4$ 回 くり返して完全に脱水固定を行った。そして細胞浮遊 
液を冷却しておいたスライドガラス上に 1 滴落とし火 焰固定を行なってからギムザ染色をした。染色体数は 原則として25個の広がりの良好な分裂中期核板につい てその数を数えまた写真撮影し核型分析に用いた。

G-band (16)：0.25\%トリプシン (Gibco) と Versen (1:5000 EDTA, Gibco) の 1:3 溶液に 30 90秒浸し消化処理後, $70 \%$ ルコールを通し反応を停 止した後ギムザ染色を行なった。ギムザ染色液は $\mathrm{pH}$ 6.4 の P.B.S. で 20 倍に希釉したものを用い 5 〜 10 分 間染色した。

Q-band (1)，(21)：スライド標本を 0.005\%キナク リンマスタード液 (Quinacrine mustard dehydrochloride, sigma）で空温にて 20 分閒染色した。過剩 の染色液を蒸留水で充分洗浄後 MacIlvaine buffer （pH 4.1）にて2 回洗い，カバーグラスで封入した。 観察には落射式蛍光顕微鏡（オリンパス, BHB）を用 いた。

C-band : Sumner ら(18)の BSG 法を実施した。 標本を $0.2 \mathrm{~N} \mathrm{HCI}$ に 1 時間浸した後, 軽く水沙し $50^{\circ} \mathrm{C}$ の $5 \% \mathrm{Ba}(\mathrm{OH})_{2}$ に ～10分間浸す。水洗後 2 倍の $\mathrm{SSC}$ (0.3M NaCl. 0.03M sodium citratesolution) に $60^{\circ} \mathrm{C}$ で 1 ～時間浸して水洗後ギムザ染色を行な った。本法は isochromosome を疑われる症例につい てのみ実施した。

\section{結果}

沪胞性リンパ腫 : 沪胞性リンパ腫 9 例中 4 例が 47 本

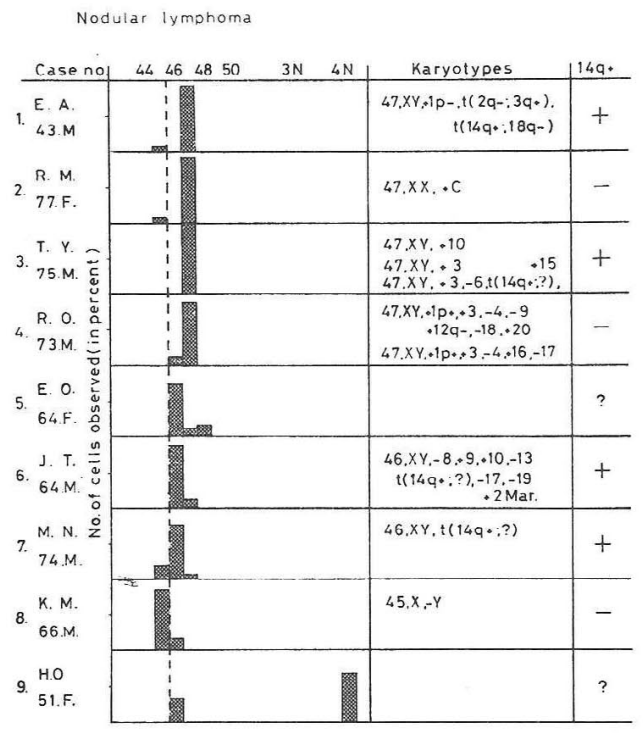

図 1 汇胞性リンパ㧱の染色体数の分布。 9 例中 4 例に 47 本にモードがある。

のモードを有した（図１）。

このらち 3 例に 3 番染色体の異常が共通してみられ た（図 2 )。その他の 4 例は漂湮 2 倍体領域にあるが 前後へのばらつきが認められ，症例 6 のように全体の 染色体数は46本でも複雑な異常を示す例もある。これ ら染色体異常と細胞構成の関係は例数も少なく分析で きていない。1例は4 倍体領域にモードがありこのの 例は沪胞性掞よびびまん性の大細胞型であった。

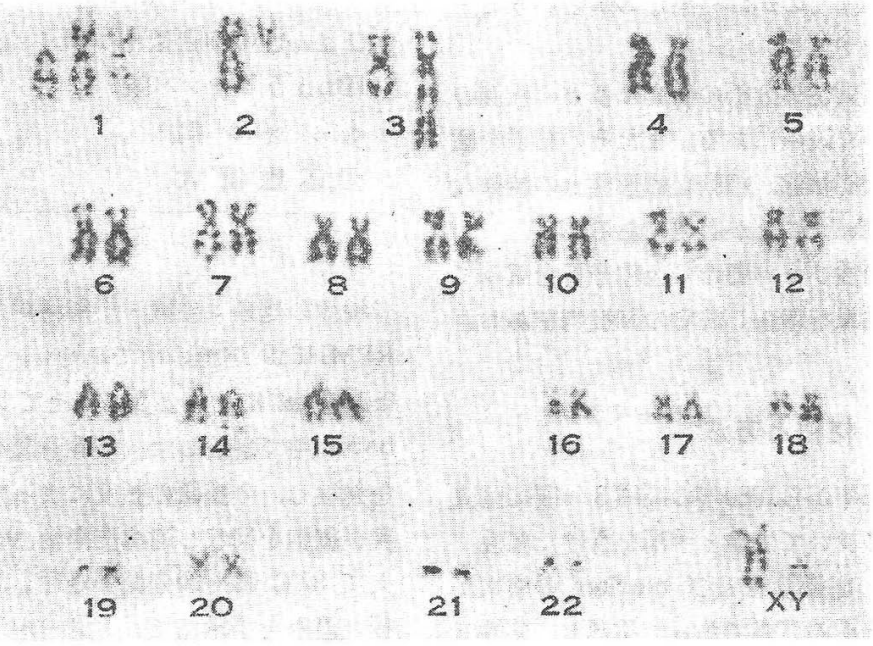

図 2 沪胞性リンパ腫の㤥型。14q+染色体の存在する一例。donor は第18番染色体の長腕 (18q 21) と拈もわれる。症例 1 , E.A. 43才, G-band。 
Diffuse large iymphoid

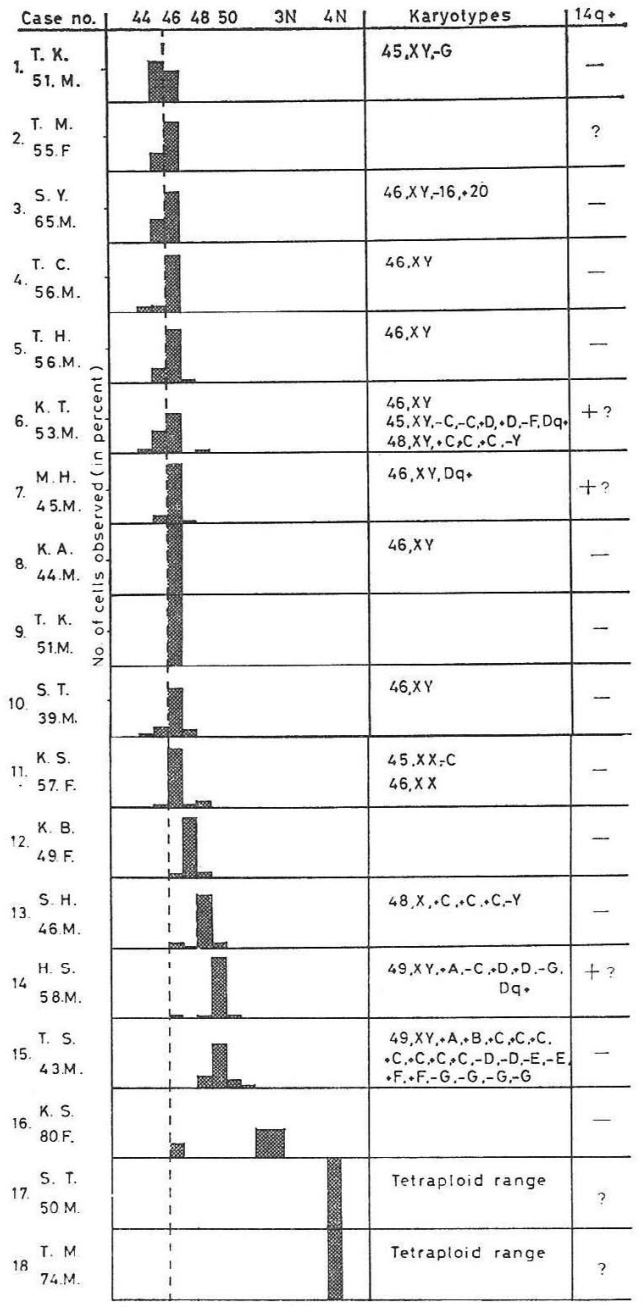

図 3 びまん性大細胞型リンパ腫の染色体数の分 布。モードは症例により45本から 4 倍体領 域にまでさ屯ざせである。

びまん性大細胞型リンパ腫 : 18例のびをん性大細脚 型リンパ瘇は 2 倍体領域のもの11例, 高 2 倍体領域の もの 2 例，3倍体領域に近いもの 3 例，4倍体領域の もの 2 例であった（図 3 ）。2 倍体, 高 2 倍体領域の ものは調べた範囲では染色体数の増減はC 群の斯常に よることが多かった。14q +の琶められたのは $3 / 14$ であった。null-D.L.L の 1 例 (小児) は46本のモード を有し、ばらつきも 2 倍体領域にとどおっていた。そ

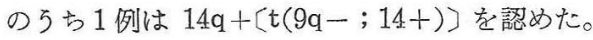

多形細胞型リンパ腫 : 未梢 $\mathrm{T}$ 細胞性腫瘏の代表的な 多形細胞型リンパ腫 3 例中 2 例は 4 倍体領域にモード
を有しておうり，残る 1 例もリンパ節生検では 2 倍体領 域にモードがあっても支痛牛検からは 4 倍体領域の細 胞が得られるなど，細胞形態の多形性に対応するよ5 に思われた（図 4, 5）。

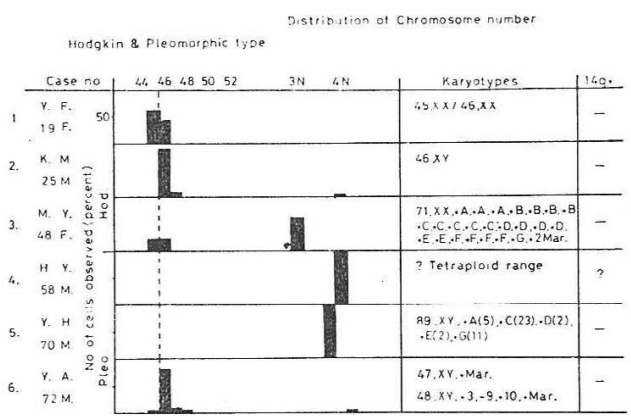

図4多形紲胞型（症例 4, 5, 6) およびホジキ ン病（症例 $1,2,3$ ）の染色体数の分布。 多形細胞型では 2 倍体および $3 ， 4$ 倍体領 域と染色体数のばらつきが多い。

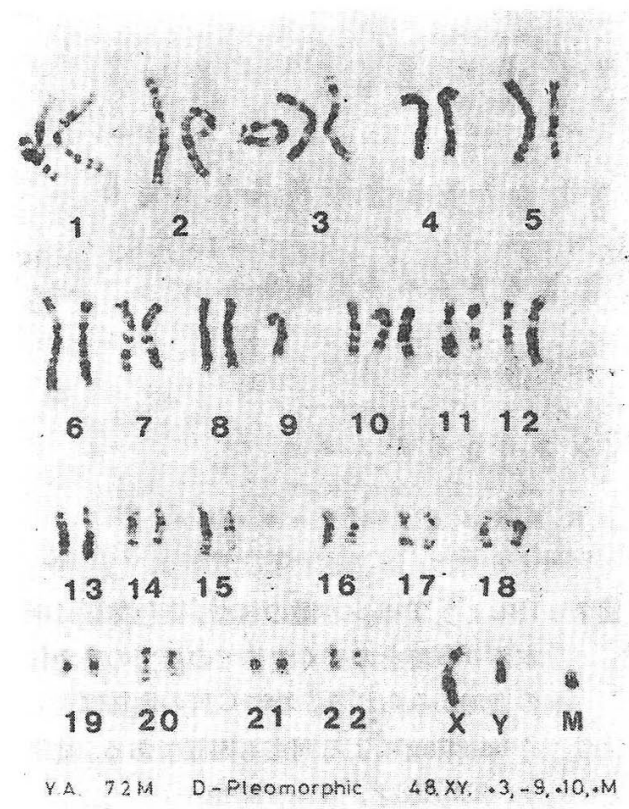

図 5 多形細胞型リンパ尰の核型。この核型は 3 , 10の trisomy, 9 の monosomy, マーカ 一染色体の出現をみる。

IBL よ5 Tリンパ腫： 5 例中 3 例は46本にモードを 有しばらつきも少ない。一方，他の 2 例では各々 48 本，66本のモードを有し腫寡性性格が明らかであっ 


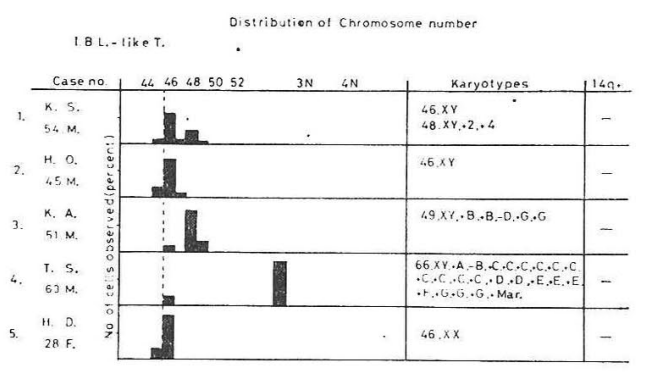

図 6 I BLようTリンパ厙。5 例中 3 例に明らか な哄常な染色体数のモードが認められる。
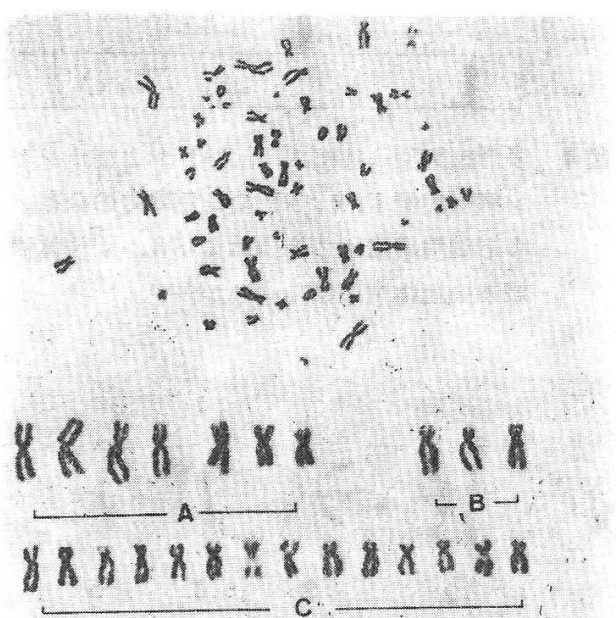

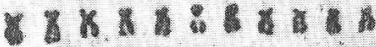

A 18 औ 0 ด

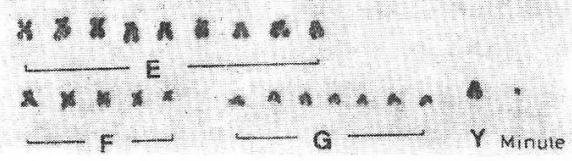

図 7 IBLよ5 Tリンパ腫の核型。染色体数は66 本あり B群をのぞくすべての群での染色体 の増加がみられる。特にC 群の増加は著し く bandingによる同定も困難である。症例 4，T.S. 63才，ギムザ染色。

\section{た（図 6,7)。}

その他：ホジキン病では 3 例中 1 例が 3 倍体領域 (モード 71) にあった（図 8)。この症例は NS 型で Lacunar cell が多く, 異型分裂像も目立った。

伝染性单核症を含むりンパ節肥大例では染色体は46 本でばらつきもほとんどなく， banding でも構造異 常は認められなかった。14.q +染色体も認められなか った（図 9)。

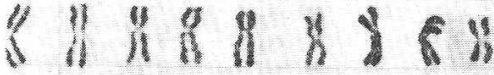

\section{A $1 \quad A 2 \quad A 3$}

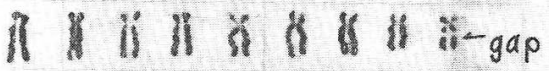

$$
B 4-5
$$

i) I)

$$
\text { c } 6-12
$$

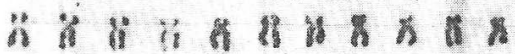

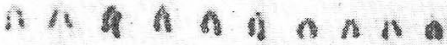

$$
\begin{aligned}
& \text { D } 13-15
\end{aligned}
$$

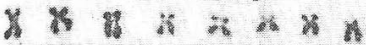

$$
\begin{aligned}
& \text { E16- }-18 \\
& \text { * if } 2 \text { ) } 4 \text { is } n \text { * } \\
& F 19-20 \\
& \text { a } a+\infty \text {. } \\
& \text { C } 21-22 M 1-2 \\
& \text { MY. } 48 \mathrm{~F} \text { Hodgkin Mode } 71 \times x
\end{aligned}
$$

図 8 ホジキン病の核型。gap（矢印）を有する 染色体や minute (微小) 染色体 (M1-2) の存在老㴓めた。図 4 症例 3，M.Y. 48才, ギムザ染色。

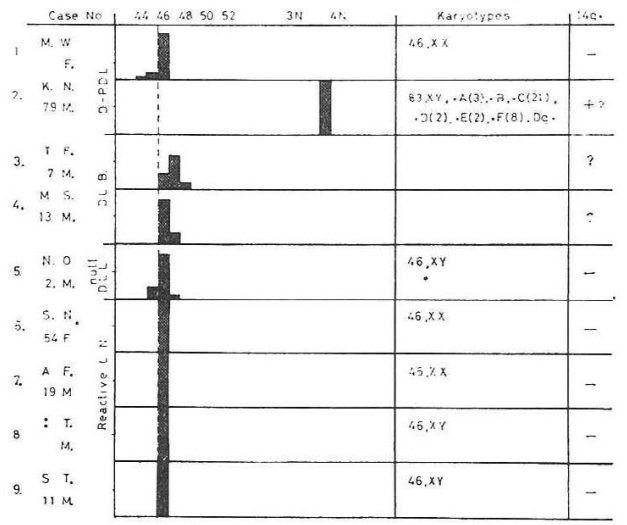

図 9 びまん性中細胞型, マーカーを有さない大 細胞, 反心性肥大のリンパ節細胞の染色体 数の分布。反応性リンパ節（伝染性単核症 を含も）では全例に数的異常はない。 


\section{考按}

造血器系腫癔の染色体の研究は慢性骨髄性白血病 (CML) の約 $90 \%$ の症例に認められる $\mathrm{Ph}^{1}$ 染色体 (11)， (14)の研究によって大きく進歩した。

悪性リンパ腫に於いては1972年に Manolov と Manolova(9) がアフリカの Burkitt リンパ腫の生検 材料より $14 \mathrm{q}$ 十染色体を発胃して以来, 多くの研究者 が追試しているが，Fukuhara ら(5)，(8) は一連の仕 事によってかなり高率に発見したと報告している。我 々の例では18.6\%であり，従来いわれるほどには高い ものとは思えないが, $14 \mathrm{q}+$ 染色体陽性例にしても $\mathrm{Ph}^{1}$ のようにほとんど全ての腫晹細胞に現れるとい5訳で はないようなので，更に多数の核分裂像を調べれば陽 性率の増加する可能性はある。高月ら(19)の成人 T 細 胞性白血病でも $14 \mathrm{q}+$ 染色体の存在が報告されている ので, Burkitt リンパ腫の特宣的異常としての価值は 減少してきている。しかし Burkitt リンパ腫は第 8 染色体との転座が大部分にみられるのに比し，その他 のリンパ腫では第 8 染色体以外（第 $1,3,4,11,14$, 15, 18 など）との転座のことが多い。これは AKRマ ウスの胸腺リンパ腫には第15染色体のトリソミーが高 率に発生すること(4) と同じように人では第14染色体 異常がリンパ球の増殖巽常に密接に関連していること を示唆する当のか子知れない。

今回の検索で比較的目立ったものに沪胞性リンパ腫 のA群の増加，とくに第 3 染色体の異常がある。 Rowley ら(15) は血液疾患に第 1 染色体のトリソミ一

\section{文}

1) Casperson, T., Zech, L. and Johansson, C.: Analysis of the human metaphase chromosome set by aid of DNA binding fluorescent agents. Exp. Cell. Res. 62 : 490-492, 1970

2) Catovsky, K.: $\mathrm{Ph}^{1}$-positive acute leukemia and chronic granulocytic leukemia: one or two disease ? Brit. J. Haemat. 42 : 493-498, 1979

3) Chessells, J.M., Lawler, S.D. and Seckewalker, L.M.: The $\mathrm{Ph}^{1}$ chromosome in childhood leukemia. Brit. J. Haemat. 41 : 25-41, 1979

4) Dofuku, R., Bielder, J.L., Spengler, B.A. and Old, L.J.: Trisomy of chromosome 15 in spontaneous leukemia of AKR mice. Proc. Nat. Acad. Sci. $72: 1515,1975$
が高頻度でみられることを総説しているが，その中で の覀性リンパ腫は少なく，むしろ CML，急性前骨髄 性白血病に高率である。リンパ・骨蹃系腫湟細胞の第 3 染色体異常は Philip ら(12)によって指摘されてい るが組織型との関連は明らかでない。欧米では沪胞性 リンパ腫が高率であるのでそのためという可能性もあ る。B-びまん性大細胞型 18例中 47本に mode のあ るのは 1 例しかないのに比べると, 沪胞性リンパ腄の 4/9 とい5のは高率であり，何らかの意味を示唆する ものか子知れない。

Immunoblastic lymphadenopathy(IBL) は, Lukes ら(8)によって提唱された疾愳概念であり，彼らはB 細胞の過形成状態と考え，リンパ腫の前段階にあると 考光ている。渡辺ら(20)は IBL に類似した臨㦿組織 像を呈しながら本態が T リンパ腄によるものを IBL ようTリンパ隀として提唱してきた。その $2 / 5$ 例に明 らかな染色体異常がみられ腫㾮性性格が明らかになっ たものと思われる。IBL は prelymphoma として考 えられることが多いが，哭際に報告されているいくつ かの例では明らかな界常核型を示すという報告もあ り（7)，(13)㫮なるリンパ腫の前段階とい5だけでな く，いくつかの罣った䠶想グループが混在している可

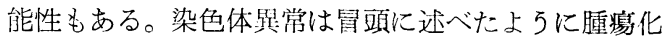
の原因か結果かということは不明のまをであるが，異 営の浔められるものの腫煌性性格は明らかであると思 われ，組織診断で良性・悪性の判断に迷らような時に 手助けになることも多い。染色体分析は腫演化の本暂 的部分に深く関係しているので今後更に症例の蓄積と 多角的な分析が必要な分野と思われる。

\section{献}

5) Fukuhara, S. and Rowley, J.D.: Chromosome 14 translocations in non-Burkitt lymphomas. Int. J. Cancer 22 : 14-21, 1978

6) Fukuhara, S., Shirakawa, S. and Uchino, H.: Specific marker chromosome 14 in malignant lymphomas. Nature 259 : 210-211, 1976

7) Hossfeld, D. K., Höffken, K., Schmidt, C. G. and Diedrichs, H.: Chromosome abnormalities in angioimmunoblastic lymphadenopathy. Lancet $24: 198,1976$

8) Lukes, R.J. and Tindle, B.H.: Immunoblastic lymphadenopathy; A hyperimmune entity resembling Hodgkin's disease. N. Eng. J. Med. $292: 1-8,1975$ 
9) Manolov, G and Manolova, Y.: Marker band in one chromosome 14 from Burkitt lymphomas. Nature $237: 33-35,1972$

10) McCaw, B. K., Epstein, A. L., Kaplan, H. S. and Hecht, F.: Chromosome 14 translocation in African and north American Burkitt's lymphoma. Int. J. Cancer $19:$ 482-486, 1977

11) Nowell, P. C. and Hungerford, D. A.: Chromosome studies on normal and leukemic human leukocytes. J. Nat. Cancer Inst. $25: 85$ $-109,1960$

12) Philip, P.: A vulnerable point on human chromosome 3 in myeloproliferative disorders? Hereditas $81: 124-125,1975$

13) Reeves, B. R and Stathopoulos, G. : Cytogenetic and cell surface marker studies in two non-Hodgkin's lymphoma of T-cell origin. Hum. Genet. 31 : 203, 1976

14) Rowley, J.D.: A new consistent chromosomal abnormality in chronic myelogenous leukemia identified by Quinacrine fluorescence and Giemsa staining. Nature 243:290-293, 1973

15) Rowley, J.D.: Abnormalities of chromosome 1 in myeloproliferative disorders. Cancer 36 : 1748, 1975
16) Seabright, M.: A rapid banding technique for human chromosome. Lancet II : 971, 1971

17）須知泰山，若狭治毅，三方淙男，難波紿二，菊地 昌弘, 森茂郎, 毛利昇, 渡辺昌, 社本幹博, 田島和 雄, 張ケ谷健一, 桐野有爾, 高木敬三, 福永真治, 板垣哲朗, 松田幹夫 : 非ホジキンリンパ腫病理組織 診断の問題点一新分類の提案 最新医学, 第34巻・ 第 9 号 昭和 54 年

18) Sumner, A. T. : A simple technique for demonstrating centromeric heterochromatin. Exp. Cell Res. 75 : 304-306, 1972

19）高月清, 内山卓, 上島嘉美, 服部俊夫 : 成人 $\mathrm{T}$ 細 胞性白血病・リンパ腫, 第39回日本癌学会総会記 事 18 , 昭和 55 年

20) Watanabe, S., Shimosato, Y., Shimoyama, M., Minato, K., Suzuki, M., Abe, M. and Nagatani, T.: Adult $\mathrm{T}$ cell lymphoma with hypergammaglobulinemia. Cancer $46: 2472-2483,1980$

21）山田清美 : 监光染色法による染色体の同定。最新 医学，第27巻：第 6 苛 炤和 47 年

22) Zech, L., Haglund, V., Nilsson, K. and Klein, G.: Characteristic chromosomal abnormalities in biopsies and lymphoid-cells from patients with Burkitt and non-Burkitt lymphomas. Int. J. Cancer 17 : 47-56, 1976 